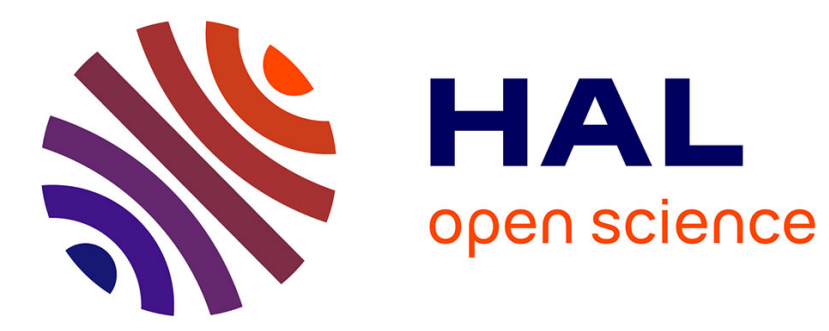

\title{
Advances in the study of mega-tsunamis in the geological record
}

Raphael Paris, Kazuhisa Goto, James Goff, Hideaki Yanagisawa

\section{To cite this version:}

Raphael Paris, Kazuhisa Goto, James Goff, Hideaki Yanagisawa. Advances in the study of mega-tsunamis in the geological record. Earth-Science Reviews, 2020, 210, pp.103381. 10.1016/j.earscirev.2020.103381. hal-02964184

\section{HAL Id: hal-02964184 \\ https://hal.uca.fr/hal-02964184}

Submitted on 12 Nov 2020

HAL is a multi-disciplinary open access archive for the deposit and dissemination of scientific research documents, whether they are published or not. The documents may come from teaching and research institutions in France or abroad, or from public or private research centers.
L'archive ouverte pluridisciplinaire HAL, est destinée au dépôt et à la diffusion de documents scientifiques de niveau recherche, publiés ou non, émanant des établissements d'enseignement et de recherche français ou étrangers, des laboratoires publics ou privés. 


\section{Advances in the study of mega-tsunamis in the geological record}

2

Raphaël Paris ${ }^{1}$, Kazuhisa Goto ${ }^{2}$, James Goff ${ }^{3}$, Hideaki Yanagisawa ${ }^{4}$

${ }^{1}$ Université Clermont Auvergne, CNRS, IRD, OPGC, Laboratoire Magmas et Volcans, F-63000 ClermontFerrand, France.

${ }^{2}$ Department of Earth and Planetary Science, The University of Tokyo, Hongo 7-3-1, Tokyo, Japan.

${ }^{3}$ PANGEA Research Centre, UNSW Sydney, Sydney, NSW 2052, Australia.

${ }^{4}$ Department of Regional Management, Tohoku Gakuin University, Tenjinsawa 2- 1- 1, Sendai, Japan.

\section{Abstract}

Extreme geophysical events such as asteroid impacts and giant landslides can generate megatsunamis with wave heights considerably higher than those observed for other forms of tsunamis. In this paper, we review recent advances in the study of mega-tsunamis in the geological record, focusing on well-documented examples that have captured particular attention over the past decade. We provide up-to-date background on the source mechanisms of tsunami generation during asteroid impacts and ocean-island landslides, which are the largest landslides on Earth. We also discuss the main sources of uncertainty for modelling such mega-tsunamis, and for addressing associated hazards.

\section{Introduction}

The 2011 Tohoku-oki and 2004 Indian Ocean tsunamis were occasionally described as "mega-tsunamis", not only in the media but also in peer-reviewed literature (e.g. Lekkas et al., 2013), probably because they were the largest ones observed in the modern era (Goff et al., 2014). However, there is evidence in the geological record for rare but extreme events, with wave heights considerably larger than those observed during the 2011 and 2004 tsunamis (e.g. Moore and Moore, 1984; Bourgeois et al., 1988).

As a background to this discrepancy, it is important to recognize the fundamental difference in viewpoints between geologists, other scientists and the public regarding hazards. For instance, 
as commonly observed in risk assessment (Fig. 1), event probability decreases with an increase in hazard intensity (e.g., Kawata, 2003). Engineers and government agencies have to set thresholds of design force to enable infrastructure to be built for protection against hazards. However, although the frequency is low, some events are larger than this design force and as such, the protection that has been constructed can fail. For such overwhelming hazards, engineers and government agencies have to estimate a maximum size that they can reasonably prepare for reducing damage. Sometimes, people misunderstand this and assume that this maximum hazard is actually the real maximum, but larger hazards can still occur although at such a low frequency that we consider them negligible in a human lifetime. These hazards are beyond the limit of modern-style disaster prevention countermeasures so that when they do occur they are most definitely "unexpected (or "souteigai" in Japanese) hazards" (Goff et al., 2014). The 2011 Tohoku-oki and the 2004 Indian Ocean tsunamis were examples of these kinds of unexpectedly large events. Depending on the people who study these larger hazards, they use various terms such as "maximum", "unexpected" and "mega" events.

In contrast, geologists who study the Earth's history usually investigate extreme hazards such as asteroid impacts, large igneous provinces, snowball earth, etc. Without doubt, these events are hazards with global impacts and are far beyond the normal-style risk assessment (Fig. 1); these hazards can lead even to mass extinctions. Compared with these extreme hazards, "normal" hazards which occur over intervals of 100s to 1000s of years (e.g., large earthquakes and tsunamis) are quite frequent and relatively small events from a geological point of view. Sometimes these events are below the resolution and detection limits of geological research. Indeed, even recent large events such as the 2011 Tohoku-oki and the 2004 Indian Ocean tsunamis are probably only just large enough that sedimentary evidence for them will be preserved in strata over geological timescales. Also, geologically speaking, the occurrence of these events is not unexpected.

The discrepancy is in terms of the human perspective. While risk assessment is carried out from the human perspective (datum on the left-hand side of the horizontal axis in Figure 1), geologists study it from the point-of-view of deep time (datum on right-hand side of the horizontal axis in Figure 1). This is essentially why geologists generally consider that neither the 2011 Tohoku-oki nor the 2004 Indian Ocean tsunamis should be called "mega-tsunamis" since they know that there have been far larger events (or they consider that evidence for larger events is still undiscovered) that deserve to be called as such; "Mega" defines the largest events we know about at the moment. 
Goff et al. (2014) proposed that the term "mega-tsunami" should be reserved for tsunamis with an initial wave amplitude exceeding $50 \mathrm{~m}$ at their sources, thus excluding all tsunamis generated by historical earthquakes. Paris et al. (2018) adopted the following definition: mega-tsunamis have a magnitude exceeding all published tsunami magnitude scales. Whatever the definition, among all the possible source mechanisms of tsunamis, only large landslides and asteroid impacts have the potential to generate mega-tsunamis.

With a maximum runup of $524 \mathrm{~m}$, the 1958 tsunami in Lituya Bay (Miller, 1960) could be considered as the only historical example of a mega-tsunami. However, this exceptional runup was caused by the restriction due to the slope just opposite the source landslide $\left(30.6 \times 10^{6}\right.$ $\mathrm{m}^{3}$ ) and values of runup rapidly decreased down to $10 \mathrm{~m}$ at $12 \mathrm{~km}$ from the source. By comparison, the December 2018 Anak Krakatau volcano flank collapse had a volume three times larger (>0.1 km³: Gouhier and Paris, 2019) than the Lituya Bay landslide, and an initial leading positive water displacement of 50 to $80 \mathrm{~m}$ (Grilli et al., 2019; Paris et al., 2019). Following the definition proposed by Goff et al. (2014), the 2018 Anak Krakatau tsunami could thus enter the mega-tsunami category, but the wave heights observed on the coasts of Sumatra and Java (40-60 km away from the volcano) were lower than $7 \mathrm{~m}$ (Takabatake et al., 2019; Muhari et al., 2019), which falls far from the maximum wave heights of the 2004 Indian Ocean (Lavigne et al., 2009) and 2011 Tohoku-oki tsunamis (Mori et al., 2012). Volumes of the 1958 Lituya Bay and 2018 Anak Krakatau landslides are at least one order of magnitude lower than the largest historical volcano flank failures that generated tsunamis, i.e. 1888 Ritter Island (5 km³: Cooke, 1981; Johnson, 1987), and 1741 Oshima-Oshima (2.4 km²: Satake and Kato, 2001). Mass transport deposits on the seafloor and giant collapse scars on the flanks of ocean islands with volumes of tens to hundreds of $\mathrm{km}^{3}$ support the existence of even larger events in the geological record (e.g. Moore et al., 1989; Carracedo et al., 1999; Oehler et al., 2004; Masson et al., 2002, 2008).

The sizes of the clasts moved upward by a tsunami can be compared between modern, historical, and geological events. Coastal boulders with a mass of $\sim 50$ to 700 tonnes have been transported by modern and historical events such as the tsunamis in the Indian Ocean in 2004 (85 tonne, Sumatra: Paris et al., 2009), Tohoku-oki in 2011 (690 tonne, Tanohata: Iwai et al., 2019), Krakatau in 1883 (200 tonne, Java: Verbeek, 1886), and Meiwa in 1771 (216 tonne, Ishigaki Island: Goto et al., 2010), but all were deposited on the coastal lowland. Tsunami waves caused by ocean island flank collapses have the potential to carry clasts that are considerably heavier and higher above sea level. In the Cape Verde Islands, Ramalho et al. 
(2015) reported boulders up to 700 tonnes, which were quarried from the edge of a palaeocliff (presently at 160-190 m above present sea level (a.p.s.l.)) and transported upwards to $220 \mathrm{~m}$ a.p.s.l. The likely cause was a mega-tsunami generated by a massive flank collapse of Fogo volcano at ca. 70 ka (Day et al., 1999; Masson et al., 2008; Paris et al., 2011; Ramalho et al., 2015). However, the largest known tsunami boulders have been found on Tongatapu Island, Tonga (1600 tonnes: Frohlich et al., 2009) and Shimoji Island, Japan (2500 tonnes: Goto et al., 2010).

In this paper, we briefly provide some background on pioneering studies of the sedimentary signatures of mega-tsunamis generated by ocean island flank collapse and asteroid impact, and we discuss the main conclusions and perspectives that must be drawn from studies of the last decade. For a detailed review of the characteristics of mega-tsunami conglomerates on ocean islands, we refer to Paris et al. (2018).

\section{Marine conglomerates at high elevation on the flanks of ocean islands}

\section{Debated evidence of mega-tsunamis in Hawaii...}

The origin of elevated marine conglomerates on the flanks of the Hawaiian Islands has long been debated since Moore and Moore (1984) revisited the Hulope Gravel (southern Lāna'I, up to $326 \mathrm{~m}$ a.p.s.l.), previously presented as an ancient littoral deposit (Stearns, 1938), and concluded that it was actually laid down by a tsunami. Similar fossiliferous conglomerates in Moloka'I (Moore et al., 1994) and Big Island (McMurtry et al., 2004) later contributed to the controversy. The different arguments in favour or against the tsunami hypothesis have been widely discussed (e.g. Grigg and Jones, 1997; Felton et al., 2006; Crook and Felton, 2008) and we refer to Paris et al. (2018) for a comprehensive review. The interpretation of the conglomerates also needs to account for the history of vertical motion of the Hawaiian Islands, and the dating of coral clasts in their deposits. In short, voluminous landslide and slump deposits on the seafloor around Hawaii (e.g. Moore et al., 1989; Normark et al., 1993), reefs drowned by long-term subsidence (e.g. Moore and Fornari, 1984; Webster et al., 2007), and coeval ages of coral clasts from different islands (Rubin et al., 2000; McMurtry et al., 2004) strongly support the hypothesis of mega-tsunamis related to flank failures. 
128 In parallel to studies in Hawaii, another "unusual" marine deposit was interpreted as being 129 caused by a mega-tsunami in the Canary Islands. In the Agaete Valley (western Gran 130 Canaria), Perez-Torrado et al. (2006) described a fossiliferous conglomerate attached to the 131 slopes at elevations ranging between 41 and $188 \mathrm{~m}$ a.p.s.l., a stratigraphical position that does 132 not fit into the framework of relative sea-level changes and uplift of Gran Canaria Island 133 (Meco et al., 2007), i.e., it cannot easily be interpreted as a paleo-beach deposit. Perez134 Torrado et al. (2006) thus concluded that it was most likely created by a tsunami caused by a 135 massive collapse, with the Güímar event on the eastern flank of Tenerife Island being the best 136 candidate.

137 During the last decade, mega-tsunami deposits were also found in the Cape Verde Islands 138 (Paris et al., 2011; Ramalho et al., 2015; Madeira et al., 2020), which is not surprising 139 considering the number of massive flank collapses that have affected these islands (Masson et 140 al., 2008), including the Late Pleistocene Fogo collapse (Day et al., 1999). On northern 141 Santiago Island, mega-tsunami evidence is provided by fossiliferous conglomerates and 142 boulders at elevations up to $100 \mathrm{~m}$ and $220 \mathrm{~m}$ a.s.l. respectively (Paris et al., 2011; Ramalho et 143 al., 2015). The Santiago conglomerates share many sedimentological characteristics with their 144 Hawaiian and Canarian counterparts: complex but diffuse internal organisation with a poor 145 lateral continuity of the subunits, poor sorting, landward and seaward imbrication of the 146 clasts, heterogeneous composition of locally derived volcanic rocks and mixed taxa of 147 shallow and deep-water fossils (never in life position, often fragmented) (Fig. 2), an erosive 148 base with rip-up clasts of the underlying substratum, and downward-injected veins of 149 conglomerates (clastic dykes) inside the palaeosol (Paris et al., 2011). The megaclasts 150 reported by Ramalho et al. (2015) were transported upwards from a cliff edge presently at 151 160-190 m a.p.s.l. (Fig. 2) to elevations up to $220 \mathrm{~m}$ a.p.s.l. (equivalent to a runup of $270 \mathrm{~m}$ 152 above coeval seal-level) and $650 \mathrm{~m}$ from their source. The largest megaclast measured $1539.4 \times 6.8 \times 3.8 \mathrm{~m}$ and had an estimated mass of 700 tonnes. ${ }^{3} \mathrm{He}$ exposure ages of the megaclasts 154 range between 65 and $84 \mathrm{ka}$, with an arithmetic mean age of $73 \mathrm{ka}$ (Ramalho et al., 2015), 155 which is concordant with the age of the last massive flank collapse of Fogo Island volcano ca. 
70 ka (Foeken et al., 2009; Cornu et al., 2017), and with the age of another tsunami conglomerate recently identified on Maio Island (Madeira et al., 2020).

Quaternary deposits are particularly well preserved in the Cape Verde Islands, making them useful for identifying tsunami deposits within a complex framework of elevated marine terraces, littoral deposits, and alluvial fans (e.g. Madeira et al., 2020). For a detailed review of the sedimentological criteria used for distinguishing mega-tsunami conglomerates from other coastal deposits, we refer to Perez-Torrado et al. (2006) and Paris et al. (2011, 2018), but many of the criteria listed by Paris et al. (2018) in their Table 1 are not specific to tsunamis. Paris et al. (2018) identified three specific criteria: (1) the succession of landward and seaward clast imbrication; (2) the increasing abundance of terrestrial material upward and landward; (3) and the mixed and unusually rich fauna, ranging from terrestrial to circa-littoral species (Fig. 2). Following these criteria, a number of mega-tsunami conglomerates have been identified, not only in the Canary Islands (Meco, 2008; Paris et al., 2017) or the Cape Verde Islands (Madeira et al., 2020), but also on Mauritius(Paris et al., 2013). In Maio, Madeira et al. (2020) reported four distinct tsunamis occurring over the last 500 kyrs, including the Fogo tsunami previously identified on Santiago by Paris et al. (2011) and Ramalho et al. (2015). The runup on Maio was in excess of $60 \mathrm{~m}$ above coeval sea level at $120 \mathrm{~km}$ from Fogo volcano, compared to a runup of $270 \mathrm{~m}$ on Santiago at $70 \mathrm{~km}$ from Fogo.

\section{Other candidate islands?}

With more than 40 flank failures identified over the last 2 Ma (Labazuy, 1996; Oehler et al., 2004), Réunion Island represent a significant source of mega-tsunamis in the Indian Ocean. However, there is so far only one published study on mega-tsunami deposits related to the impact of a Réunion Island flank collapse on the southern coast of Mauritius Island, where Paris et al. (2013) reported reef megaclasts and a tsunami conglomerate at elevations up to 40 $\mathrm{m}$. The maximum age of the tsunami is given by a ${ }^{14} \mathrm{C}$ age of $4425 \pm 35 \mathrm{BP}$ on a coral branch, which is concordant with that of the last flank collapse on the eastern flank of Piton de la Fournaise volcano on Réunion Island (Labazuy, 1996; Oehler et al., 2004). The humid climate of Mauritius and Réunion Islands does not allow tsunami deposits to be as well preserved as in the Canary and Cape Verde Islands, but other mega-tsunami evidence might yet be discovered in Rodrigues Island or Madagascar. 
187 In the Atlantic Ocean, studies in the Cape Verde and Canary Islands should be extended to the 188 Azores (Andrade et al., 2006), where large-scale mass wasting has been documented, especially on the southern flank of Pico Island (e.g. Mitchell et al., 2011; Costa et al., 2015). However, there is so far no report of mega-tsunami deposits that could be related to flank collapses in the Azores. The same is true for the southern Pacific Islands. Quaternary flank collapses in the Society and Marquesas Islands (e.g. Clouard et al., 2001; Clément et al., 2002; Hildenbrand et al., 2006) might have generated mega-tsunamis whose traces are yet to

194 be identified. Blahüt et al. (2019) recently created a worldwide database of "giant landslides 195 on volcanic islands" (https://www.irsm.cas.cz/ext/giantlandslides/index.php) which can provide a general framework for completing the catalogue of mega-tsunamis.

\section{Multistage flank collapses}

199

200

201

202

203

Following the seminal work of Perez-Torrado et al. (2006), Madeira et al. (2011) described new sections in the Agaete Valley (Gran Canaria) and they found two other tsunami conglomerates below the one described by Perez-Torrado et al. (2006). This succession of three tsunami deposits in the same valley not only illustrates the recurrence of massive flank collapses in the Canary Islands, but it also raises the following question: do ocean island mega-failures collapse in one-go or retrogressively as multistage events separated by short periods of time? Answering this question is of fundamental importance for evaluating the mega-tsunami threat.

Giachetti et al. (2011) demonstrated that a multistage scenario of collapse (rather than in one go) generates a tsunami large enough to explain the maximum inundation distance inferred from the spatial distribution of tsunami deposits in the Agaete valley. Hunt et al. $(2010,2013)$ used the sequences of distal turbidites to illustrate the multistage nature of the majority of the Canary Islands flank collapses, including the Güímar collapse that produced the Agaete megatsunami. On the northern flank of Tenerife, the Icod collapse is recorded offshore by three debris lobes that were successively emplaced (Watts and Masson, 2001) and a stacked sequence of seven turbidites (Hunt et al., 2011). The compositions of the successive turbidites and their subunits vary from basaltic lavas of the submarine flank to phonolitic-trachytic lavas of the subaerial edifice, recording how successive failures removed different parts of the edifice (Hunt et al., 2011). 
218 Based on the structure of the tsunami deposits in Santiago (Cape Verde) and available 219 geophysical data offshore, whether the Fogo collapse was multistage or not is far from evident 220 (Masson et al., 2008; Paris et al., 2011). However, as for the Agaete Valley in Gran Canaria 221 (Perez-Torrado et al., 2006; Madeira et al., 2011), numerical simulations show that tsunami 222 runup resulting from a multistage failure can reproduce the spatial distribution of mega223 tsunami deposits reported by Paris et al. (2011) and Ramalho et al. (2015), whereas massive 224 collapses (in one-go) may over-estimate the runup (Paris et al., 2018).

Links between volcanic activity, flank instability, and mega-tsunami

227 Causal links between some ocean island flank collapses and major explosive eruptions was 228 unclear until new evidence of a mega-tsunami combined with explosive activity was 229 demonstrated by Paris et al. (2017) in Tenerife. Indeed, the Icod collapse on the northern flank of Tenerife was highly debated because its genesis was coeval with a major caldera-forming volcanic eruption (El Abrigo eruption and the Las Cañadas caldera: Marti et al., 1994; Ancochea et al., 1999; Edgar et al., 2007). The Icod collapse was a multistage retrogressive event that mobilised a volume of $\sim 200 \mathrm{~km}^{3}$ from both the submarine and subaerial flanks of the island (Watts and Masson, 1995, 2001; Hunt et al., 2011). Paris et al. (2017) recently proposed a scenario that links the successive flank collapses with the Abrigo eruption and two major tsunamis at ca. $170 \mathrm{ka}$. Paris et al. (2017) used the composition of tsunami deposits on the northwestern coast of Tenerife (at altitudes up to $132 \mathrm{~m}$ a.p.s.l.) to propose the following scenario: an initial tsunami was generated during the submarine stage of the retrogressive failure and before the onset of the Abrigo eruption, whereas a second and larger tsunami immediately followed the debris avalanche of the subaerial edifice and formation of the caldera. This original scenario of coupled flank collapse and explosive eruption seems to be recurrent for the central volcanic edifice of Tenerife (Hunt et al., 2018), and it represents a new type of volcano-tectonic event on ocean islands.

Numerical modelling of ocean island mega-tsunamis: learning from historical examples of landslide tsunamis tens to hundreds of meters of local tsunami run-up height. Recent developments in numerical 
simulation can help us to estimate the impact and affected areas of such events, although it is 250 a challenging exercise (e.g. Løvholt et al., 2015; Yavari-Ramshe \& Ataie-Ashtiani, 2016). The choice of parameters for numerical simulations of mega-tsunamis generated by large-scale flank collapses of ocean islands is difficult because there is no instrumental or observational data available. This is particularly well illustrated by the debate on the potential impact of a tsunami generated by a large-scale collapse of the western flank of La Palma, Canary Islands (e.g. Ward and Day, 2001; Løvholt et al., 2008; Abadie et al., 2012; Tehranirad et al., 2015).

The main factors used to determine the initial size of a landslide-induced tsunami are the volume of landslide mass, water depth, velocity of movement, landslide scenario (in one-go or multistage) and the types of landslide that are classified by movements such as rotational landslide, debris flow or avalanche (USGS, 2006), and conditions (submarine or subaerial). Compared to earthquake-induced tsunamis, landslide tsunamis can cause locally extreme runups with a high wave energy caused by the relatively short wave periods that are generated (Muhari et al., 2018). However, short period waves are likely to be significantly attenuated over a short distance (Friz et al., 2004; Heidarzadeh \& Satake, 2015; Heidarzadeh \& Satake, 2017). To simulate landslide-induced tsunamis, it is necessary to develop models of both landslide movement and the short-period tsunami waves. To explain the physics of landslideinduced tsunamis, three types of models have been proposed.

The first type of model generates the tsunami waves by inputting an initial waveform estimated by analytical, empirical or observational landform changes (e.g. Tappin et al., 2014; Grilli and Watts 2005; Satake and Kato, 2001). This method is commonly used for preliminary assessments because the model is easy and simple to use (e.g. Okamura et al., 2018). The model can also be used for the calculation of tsunamis caused by landform deformation such as caldera collapse (e.g. Ulvrova et al., 2016). However, it is difficult to estimate the interactive process between landslide movement and the resulting tsunami wave.

The second type is a two-layer model of depth-averaged equations representing the tsunami (water mass) and the landslide (soil mass) in upper and lower layers, respectively (e.g. Imamura et al., 2001; Kawamata et al., 2005). This approach was applied to simulating massive flank collapses and their resulting mega-tsunamis in Reunion Island (Kelfoun et al., 2010), Tenerife (Giachetti et al., 2012; Paris et al., 2017), and Fogo (Paris et al., 2011). Since this type of model considers the landslide as a fluid, it is adequate for simulating the tsunami caused by a debris flow or debris avalanche. As examples, Ioki et al. (2019) simulated the 
1741 tsunami caused by the sector collapse of the Oshima-oshima volcano in Japan using the

282 two-layer model with a Coulomb viscosity model to reproduce both the distribution of 283 landslide deposits and historical tsunami wave heights. Yanagisawa et al. (2018) simulated the 2841792 tsunami caused by sector collapse of Unzen Mayuyama volcano in Japan using a two285 layer model. Their model predicted that a wave amplitude greater than $50 \mathrm{~m}$ would occur 286 soon after tsunami generation. These modelling results were well validated by historical 287 information of tsunami sediments (Imamura \& Matsumoto, 1998; Tsuji et al., 2002; 2017). 288 We suggest that the two-layer approach should accurately model extremely large landslide 289 tsunamis.

290 The third type is a 3-dimentional (3D) model used to simulate landslide-generated impulse 291 waves. Mader (2002) simulated the 1958 Lituya Bay tsunami using the Navier-Stokes 292 equations for compressible fluid flow. The calculated maximum wave height in the bay was 293 about $250 \mathrm{~m}$ above sea level, which ran up to a height of $580 \mathrm{~m}$, agreeing well with the observed runup of $524 \mathrm{~m}$ (Miller, 1960). Franco et al. (2020) simulated this tsunami using the Computational Fluid Dynamics (CFD) software Flow-3D, which computes the movement of two fluids having a different density. Recently, methods that do not use gridding, such as Smoothed Particle Hydrodynamics (SPH), perform well in simulating the complex multiphase flow of a landslide-generated tsunami (Xenakis et al., 2017). There is also a hybrid using 2D and 3D models for landslide and water movement, respectively, which can accurately simulate waves with short periods with a reducing computational load for the landslide movement calculation (Ma et al., 2015; Grilli et al., 2019).

302 Although modelling is indeed useful, accuracy of the initial parameters of the landslide remains controversial because these are usually difficult to observe directly or to infer from geological data (e.g. geometry of the landslide scar, characteristics of the landslide deposits). For the 1741, 1792 and 1958 events, observations and inundation data are used to validate the model including, for example, the topography before and after sector collapses, the extent of the landslide deposit and erosional area, historical tsunami heights, and tsunami deposits; and it was therefore possible to infer the landslide parameters using these data. Since megatsunamis are a low frequency hazard we only have rare opportunities to collect sufficient evidence to determine most of the necessary parameters. With this in mind, Sassa et al. (2016) enhanced the landslide parameters for the 1792 sector collapse of Unzen Mayuyama volcano

312 by conducting ring shear stress tests on soil from the landslide material. Although these results 313 are important as a fundamental dataset, the scaling of experimental results to in situ prototype 
314 remains an issue. Therefore, it is important to collect as much accurate information as

315 possible, not only from experimental data but also from studies of recent events, such as the 3162018 Anak Krakatau tsunami (Grilli et al., 2019; Muhari et al., 2019; Paris et al., 2019).

317 Although this recent landslide tsunami was not mega, the simulation of such events is useful 318 for developing reliable models that can be later applied to the study of potential 319 megatsunamis.

\section{Asteroid impacts and mega-tsunamis}

322 Asteroid impacts are extreme phenomena that infrequently punctuate Earth's history. They 323 can drastically change Earth's environment and climate and can lead to mass extinctions 324 (Alvarez et al., 1980; Schulte et al., 2010). Since major parts of the Earth's surface are covered by oceans ( 70\%), many past (and future) impact events will have occurred in the oceans and potentially generated mega-tsunamis. However, oceanic impact craters are difficult to identify, so there are few examples recorded (they represent only $\sim 20 \%$ of all known impact craters, e.g., Jansa, 1993; Ormö and Lindström, 2000; Dypvik and Jansa, 2003). Many of them are undoubtedly waiting to be discovered (e.g., Nozaki et al., 2019), although some oceanic impact craters may well have been eroded away or subducted into the mantle over time. When seeking evidence for oceanic events, tsunami deposits with associated traces of the impact are extremely useful (e.g., Gersonde et al., 1997).

Impact-induced mega-tsunamis can also occur on other planets and satellites if water or other

334 liquids exist on their surfaces. Within our solar system, Mars is of the greatest interest since it 335 has been suggested to have had a putative ocean in its past (Ormö et al., 2004; Iijima et al., 2014; Costard et al., 2017, 2019). While the presence of an ocean on Mars is still under debate (e.g., Parker et al., 1993; Tanaka, 1997), the identification of Martian oceanic impact craters and tsunami deposits has the potential to assist further discussion about the ocean's possible existence, its depth and lifespan. On this point, the understanding of the oceanic impact process on Earth can provide crucial information for the identification of similar features on 341 other planets and satellites.

342 Among oceanic impacts on Earth, that caused by the Chicxulub asteroid, which struck the 343 Yucatàn Peninsula, Mexico, ca. $66 \mathrm{Ma}$, is currently the largest known impact. The 344 paleontological evidence of it defines the Cretaceous/Paleogene (K/Pg) boundary and the 
345 impact is now widely accepted as the major trigger of a mass extinction at this time (Schulte 346 et al., 2010). The K/Pg boundary tsunami deposits have been studied for more than 30 years since Bourgeois et al. (1988). Also, the Eltanin asteroid at 2.51 Ma (Kyte et al., 1988; Goff et al., 2012) is another interesting example of an oceanic impact event that was recognized in the absence of an impact crater. The research histories of the Chicxulub and Eltanin events and the resultant tsunami deposits are interesting examples that may serve to guide future work in identifying undiscovered oceanic impacts and resultant generation of mega-tsunamis.

\section{The K/Pg boundary tsunami deposits}

354 Since it was first proposed by Alvarez et al. (1980), there have been numerous discussions 355 about the $\mathrm{K} / \mathrm{Pg}$ impact and extinction event. The most serious weaknesses of the impact 356 hypothesis in the 1980s was the lack of conclusive evidence of an impact crater. The K/Pg boundary deposits, which were reported during the 1980s mostly around Europe and North America, are usually a few mms to cms in thickness (e.g., Alvarez et al., 1980; Smit et al., 1980). During the late 1980s, Bourgeois et al. (1988) reported meter thick tsunami deposits on the K/Pg boundary at the Brazos River in Texas, USA. It is interesting to note that this impact tsunami work was being reported at almost exactly the same time as the first scientific papers about Holocene paleotsunami deposits were being reported in the Pacific Northwest, USA (Atwater, 1987), Japan (Minoura et al., 1987) and Europe (Dawson et al., 1988). The presence of impact-induced tsunami deposits around the Gulf of Mexico indicated that the impact must have occurred close to the Gulf coast (e.g., Hildebrand and Boynton, 1990; Maurrasse and Sen, 1991). Finally in 1991, Hildebrand et al. (1991) identified the Chicxulub crater on the northern flank of the Yucatàn Peninsula. The impact site was on the Yucatàn carbonate platform and was interpreted as having occurred in relatively shallow water ( 200 m, Matsui et al., 2002).

After the discovery of the Chicxulub crater, during the 1990s and 2000s, numerous $\mathrm{K} / \mathrm{Pg}$ boundary offshore deposits were reported around the Gulf of Mexico (Maurrasse and Sen, 1991; Alvarez et al., 1992; Smit et al., 1992, 1996; Smit, 1999) and the proto-Caribbean Sea (e.g., Takayama et al., 2000). These offshore deposits have similar sedimentary features that can be characterized by some of following: 1) basal erosional contact, 2) large rip-up clasts or coarse basal spherule layer, 3) multiple sets of bi-directional cross laminations that indicate repeated reversal of flow directions, 4) massive but monotonous upward fining units with 
slight variations in grain size and/or composition, 4) they are a meter to few hundred meters thick, and 5) there is an abundance of organic matter such as wood (e.g., Smit et al., 1992, 1996; Smit, 1999; Tada et al., 2003; Schulte et al., 2012). Based primarily on these characteristics, these offshore deposits have been interpreted as having a tsunami origin (e.g., Smit, 1999). On the other hand, other researchers have suggested that these deposits can alternatively be interpreted as impact-induced turbidites or submarine landslide deposits (Bohor et al., 1996; Bralower et al., 1998) or the combination of lower gravity flow deposit and upper thick tsunami deposit (Kiyokawa et al., 2002; Tada et al., 2003; Goto et al., 2008).

Since there are very few reports of modern tsunami deposits in the deep ocean, but they seem likely to have been emplaced, the differentiation between tsunami deposits and turbidites remains an important issue for paleotsunami researchers. Indeed, submarine tsunami deposits formed by recent events have only been reported since the 2000s (e.g., Noda et al., 2007), although some possible Holocene ones were reported in the Mediterranean Sea (Kastens and Cita, 1981; Cita et al., 1996). Note that the potential offshore K/Pg tsunami deposits were studied and interpreted without any modern analogues. Following the recent 2011 Tohoku-oki tsunami, there were some reports concerning deposits formed in 100-6000 m water depth (Ikehara et al., 2014; McHugh et al., 2016). Interestingly, some of these deposits are interpreted as being a combination of a lower turbidite triggered by the earthquake or tsunami and an upper tsunami deposit (Ikehara et al., 2014; Usami et al., 2017) with peaks of Cs concentration, like the iridium anomaly of the $\mathrm{K} / \mathrm{Pg}$ boundary deposits, released from the damaged Fukushima Daiichi Nuclear Power Plant (Ikehara et al., 2014). This interpretation is similar to those of the $\mathrm{K} / \mathrm{Pg}$ boundary reported in the proto-Caribbean sea (Takayama et al., 2000) although the 2011 deposits are significantly thinner.

More recently, DePalma et al. (2019) reported an onshore K/Pg surge deposit in North Dakota, USA. The site is located $\sim 3000 \mathrm{~km}$ away from the impact site near the narrow seaway that connected to the Gulf of Mexico during the Cretaceous (DePalma et al., 2019). They proposed that the deposit was formed not by the tsunami generated by the impact but by an impact-induced seismic seiche similar to those observed in Norway following the 2011 Tohoku-oki event (Bondevik et al., 2013).

\section{K/Pg tsunami generation mechanisms}


Another important discussion concerns how the tsunami was generated by the Chicxulub impact. Bralower et al. (1998) suggested that the tsunami could have been generated by an impact induced landslide. Matsui et al. (2002) suggested mainly three generation mechanisms

411 of the K/Pg impact-induced tsunami: 1) a rim wave formed from the collapse of the large 412 splash caused by the impact, 2) impact-induced landslide, and 3) ocean water flowing into 413 (resurge) and flowing out from the crater. Tsunamis could have been generated by all of these 414 processes simultaneously with differing intensities and waveforms. For instance, Matsui et al. 415 (2002) suggested that the rim wave might have had only a small impact along the Gulf coast. 416 This is because a rim wave is characterized by a high wave amplitude with a short wave 417 period at the impact site. The tsunami may be very large around the proximal impact site but it 418 is unstable and dissipates quickly. An impact-induced landslide also has the potential to generate a large tsunami that is unidirectional. Namely, if the submarine landslide were generated off the northern flank of the impact crater (Bralower et al., 1998), a large tsunami would have been preferentially propagated northwards.

The resurge process may induce the movement of a significant volume of ocean water (Matsui et al., 2002). If this was indeed generated during the Chicxulub impact, wave periods tend to be long (10 $\mathrm{h}$ according to Matsui et al., 2002) and stable, propagating through the ocean and becoming very large along the coast. Matsui et al. (2002) estimated that the maximum run-up height around the Gulf of Mexico could have reached as high as $300 \mathrm{~m}$ and this could explain the ocean-wide distribution of tsunami deposits in the Gulf of Mexico and proto-Caribbean Sea.

The resurge should rework fallback ejecta inside the crater and so the process is testable using core samples from the site. Goto et al. (2004) and Smit et al. (2004) studied the ICDP YAX-1 cores recovered $65 \mathrm{~km}$ from the crater centre (near the crater rim) and found sedimentary features with influence of flow such as climbing ripples and repeated upward fining and coarsening units; they suggested that resurge did indeed occur following the Chicxulub impact. However, others have suggested that a large portion of the inferred resurge deposit can be interpreted as fallback ejecta (e.g., Wittmann et al., 2007). Also, if the crater rim rose high above sea level then it may have prevented ocean water flowing into the crater (Bahlburg et al., 2010). Since the water depth of the impact site was considered to be shallow, numerical modeling results indicate that only a low energy resurge might have occurred locally (Bahlburg et al., 2010). On the other hand, the resurge process might have been stronger than 
water depths around the impact site would have been much deeper than previously thought. In 2016, IODP Expedition 364 recovered continuous cores at the peak ring inside the crater (45.6 $\mathrm{km}$ from the crater centre). Gulick et al. (2019) studied the sedimentology of these cores and based on the presence of laminations and variations in grain size, suggested that resurge deposits were also present. The presence of inferred resurge deposits at the two separate sites near the crater centre and rim suggests that this process was large and occurred at a craterwide scale.

The tsunami generation process of the Chicxulub impact is still under discussion and more research including numerical modeling for sediment transport should be carried out in the future.

\section{The Eltanin impact event}

While it was originally thought that the Eltanin asteroid impact occurred around 2.15 Ma, its date has subsequently moved back to $2.51+0.07 \mathrm{Ma}$, contemporaneous with the PliocenePleistocene boundary at 2.58 Ma (Goff et al., 2012). Unlike Chicxulub, this was a deep ocean (4-5 km) impact that struck in the Southern Ocean some $1500 \mathrm{~km} \mathrm{SSW}$ of Chile. Furthermore, unlike Chicxulub there is no seafloor crater with the impact being identified through traces of intense erosion and the presence of meteoritic material in sedimentary rocks collected $500 \mathrm{~km}$ apart (Gersonde et al., 1997). The absence of a physical crater and the distribution of meteoric material have allowed researchers to estimate the asteroid diameter at between 1 and $4 \mathrm{~km}$. However, there is considerable debate concerning this diameter, which has significant implications for numerical modelling of any resultant tsunami (e.g. Korycansky \& Lynett, 2005; Ward \& Asphaug, 2002; Weiss et al., 2006; 2015). There are significant disparities between most of the model outputs, but recently Weiss et al. (2015) have produced the most comprehensive study using an assumed diameter of a mere $750 \mathrm{~m}$. This resulted in wave amplitudes between 8 and $10 \mathrm{~m}$ in southern Chile to less than a meter in northern Chile. Needless to say, if a larger diameter is used, amplitudes are larger. These results have been used to suggest that much of the proposed physical evidence for a circumSouth Pacific tsunami generated by the impact is incorrect. The size of the modelled wave means that it could not transport much of the material found in the proposed coarse-grained tsunami deposits. 
472 The geological evidence is compelling, however, so the problem lies mainly with the 473 modelling of asteroid impact tsunamis. Modelling waves produced by large sized impactors 474 becomes increasingly complex and as such it is simpler to work with a smaller diameter (Goff 475 et al., 2012). Numerous arguments have been made for the inferred size of the Eltanin asteroid 476 but ultimately it seems most reasonable to place it somewhere between 1 and $4 \mathrm{~km}$ and as 477 such we are still unclear about the possible maximum size of the tsunami wave amplitude 478 along the Chilean and other South Pacific coastlines.

479 Possible Eltanin impact related deposits have been reported around the Pacific Ocean from as 480 far north as Japan and as far south as Antarctica, with the densest concentration being along 481 the Chilean coast, largely associated with either the Ranquil or Pisco Formations (Goff et al., 482 2012). Some of these deposits have been dismissed as tsunamites through both numerical 483 modelling and geological reassessment, the most notable being those at Hornitos where the 484 tsunamite was reinterpreted as a debrite (Spiske et al., 2014). Most recently though, Le Roux 485 (2015) has questioned this reinterpretation stating that it may well still be a tsunami deposit 486 but that it could be 5.3-7.2 Ma old and therefore not related to the Eltanin asteroid impact.

487 Geological evidence for the Eltanin tsunami from other sites range from boulder deposits and 488 associated bonebeds of marine fauna, to coarse bioclastic sands, soft sediment deformation features, rip-up clasts, unconformable contacts and deeply channelled erosional features (Goff et al., 2012). This evidence generally mirrors that used to positively identify modern tsunami 491 deposits, but of particular note are the unusual bonebed deposits noted by Gersonde et al. 492 (1997) from Peru and Chile. These bonebeds contain the skeletons of rorqual whales, sperm 493 whales, seals, aquatic sloths, walrus-whales, predatory bony fish and many other species 494 (Pyenson et al., 2014). The end of the Pliocene was marked by an extinction event among 495 marine megafauna (mammals, seabirds, turtles and sharks) with $36 \%$ of Pliocene genera 496 disappearing including apex predators such as Carcharocles megalodon (the megashark) the 497 largest shark that ever lived (Pimiento and Clements, 2014; Pimiento et al., 2017). It also 498 marks the last appearance date of numerous marine microfossils (Berger, 2011). This 499 prominent die-off of marine species may well be linked to severe acoustic trauma or shock 500 waves associated with a deep ocean asteroid impact (e.g. Ketten, 1995). The 501 contemporaneous combination of bonebeds and sedimentary evidence make a compelling 502 case for an Eltanin tsunami that was larger than current modelling scenarios suggest. 
Like Chicxulub, the tsunami generation process of the Eltanin impact is still under discussion

504 and more research, particularly with respect to combined bonebed-possible tsunami deposit sequences, should be carried out in the future.

\section{Hazard assessment}

508

509

Assessing hazards related to mega-tsunamis generated by volcano flank collapse or asteroid impact amounts to a reconciliation between the human and geological perspectives. Considering the low frequency of such events and the high cost of monitoring, one could conclude that the implementation of any form of prevention strategy is not cost-effective. However, whether or not this is the case, it is the role of geologists to improve society's awareness of such extreme hazards.

Addressing mega-tsunami hazards related to volcano flank instability could start with an adequate monitoring strategy and a regional collaboration between both the volcano observatories and the tsunami warning systems. The monitoring of active volcanoes such as Kilauea in Hawaii and the Piton de la Fournaise in Reunion Island now offers the possibility to detect small flank displacements (e.g. using GNSS and InSAR), but the scientific community lacks milestones to anticipate large-scale flank collapses of ocean islands. The major eruption of Piton de la Fournaise volcano in April 2007 was associated with a large (up to $1.4 \mathrm{~m}$ horizontally) seaward motion of its eastern flank along a detachment fault (Froger et al., 2015). Although no collapse occurred, it illustrates the relevancy of InSAR for an early detection of ground motion on volcanoes. Earth observation programs such as Copernicus now give access to worldwide data from satellites, including radar imaging that can be rapidly post-processed to produce interferograms. The second step is the definition of scenarios to be used in probabilistic tsunami hazard assessment (PTHA) and Tsunami Early Warning Systems (TEWS). Given the uncertainty of the collapse mechanisms, numerical models could yield unrealistic results and any conclusions concerning hazard assessment should be viewed with caution.

Similar uncertainties weigh on the assessment of tsunamis generated by asteroid impacts. For instance, Ward and Asphaug (2003) assumed an oceanic impact of a 1950DA asteroid with 1.1 $\mathrm{km}$ diameter and found that the east coast of the United States would be inundated by a tsunami over $100 \mathrm{~m}$ high if it struck the Atlantic Ocean. Wünnemann et al. (2007) performed 
534 numerical modelling of the tsunami generation process from an small asteroid impact, which 535 predicted that the rim wave decays quickly so that it can't be treated as a long wave. Gisler et 536 al. (2011) suggested that even a relatively large asteroid with $<500 \mathrm{~m}$ diameter hit the ocean at 537 a depth of $<5 \mathrm{~km}$ depth, tsunamis would quickly dissipate and around adjacent shorelines the 538 wave height would be smaller than the 2004 Indian Ocean tsunami. These results suggest that 539 large tsunamis with long wavelengths may not be generated when the impact site is deep 540 and/or the impactor is small. Also, if the impact site is shallow and a high crater rim is 541 formed, then large tsunamis may not be generated as well. Future investigations of the most 542 effective conditions for maximizing the size of impact tsunamis need to be carried out (Goto 543 et al., 2013).

544 For hazard assessment, probabilistic analysis with information on potential impact size and 545 frequency is important (Ward and Asphaug, 2000). According to Chapman and Morrison 546 (1994), the recurrence interval over which an asteroid with a $100 \mathrm{~m}$ diameter hits the Earth is 547 about $10^{3}-10^{4}$ years and with a $1000 \mathrm{~m}$ diameter it is about $10^{5}-10^{6}$ years. While an asteroid 548 with a diameter of a few hundred meters may break up in the atmosphere so that the impact 549 frequency of small asteroids may well be lower, this effect is less likely for large asteroids 550 (Bland and Artemieva, 2003, 2006). Bland and Artemieva (2006) estimated that an asteroid 551 with a $200 \mathrm{~m}$ diameter, which may generate a hazardous tsunami, will hit the Earth's surface 552 every $\sim 10^{5}$ years, which is a far lower frequency than Ward and Asphaug (2000)'s estimated 553 (3000-4000 year interval for a $220 \mathrm{~m}$ diameter impactor).

554 Goto et al. (2013) carried out a preliminary evaluation of the tsunami hazard for the Japanese 555 coast from the impact of a $500 \mathrm{~m}$ diameter asteroid hitting 5000-m-deep ocean. In this case, 556 the impact tsunami was characterized by short wavelengths with high amplitudes. The 557 amplitude reached nearly $80 \mathrm{~m}$ in the deep ocean, decaying quickly to only a few meters when 558 it reached $50 \mathrm{~m}$ water depth. They proposed that the tsunami broke on the continental shelf far 559 away from the shoreline so that it was considerably attenuated prior to striking the coast. 560 Importance of wave breaking is known as the "Van Dorn effect" (Melosh, 2003) and is 561 important for tsunami hazard assessment of coastal communities. 
564 There is a risk of mega-tsunamis generated by ocean island flank collapses or asteroid impacts

565 in the future. Although they occur with a very low frequency compared to earthquake-induced 566 tsunamis, they can potentially be a significantly large hazard. It is extremely difficult to assess 567 and mitigate the risks associated with such high-magnitude but low-frequency hazards. Mega568 tsunamis are treated as geophysical curiosities rather than true threats, probably because their 569 recurrence interval far surpasses that of political and economic development strategies. 570 However, both the 2004 Indian Ocean and 2011 Tohoku-oki earthquakes raised awareness of 571 global disasters and their associated cascading risks. In this context, addressing future mega572 tsunami hazards requires international collaboration.

573 To end on a positive note, García-Olivares et al. (2017) used a combination of geological and 574 mtDNA data to demonstrate that ocean island flank collapses may be drivers of island 575 colonization, and subsequent lineages of diversification. Extreme geophysical events can thus have positive biotic consequences that balance out their catastrophic repercussions.

\section{References}

Abadie, S., Harris, J.C., Grilli, S., Fabre, R., 2012. Numerical modeling of tsunami waves generated by the flank collapse of the Cumbre Vieja Volcano (La Palma, Canary

Alvarez, L. W., Alvarez, W., Asaro, F., Michel, H. V., 1980. Extraterrestrial cause for the Islands): Tsunami source and near field effects. Journal of Geophysical Research 117, C05030.

Alvarez, W., Smit, J., Lowrie, W., Asaro, F., Margolis, S. V., Claeys, P., Kastner, M., Hildebrand, A., 1992. Proximal impact deposits at the Cretaceous-Tertiary boundary in

Ancochea, E., Huertas, M.J., Cantagrel, J.M., Coello, J., Fúster, J.M., Arnaud, N., Ibarolla, E., the Gulf of Mexico: A restudy of DSDP, leg 77 sites 536 and 540. Geology 20, 697700. 1999. Evolution of the Cañadas edifice and its implications for the origin of the Las Cañadas Caldera (Tenerife, Canary Islands). Journal of Volcanology and Geothermal Research 88, 177-199. 
Andrade, C., Borges, P., Freitas, M.C., 2006. Historical tsunami in the Azores archipelago (Portugal). Journal of Volcanology and Geothermal Research 156, 172-185.

Atwater, B. F., 1987. Evidence for great Holocene earthquakes along the outer coast of Washington State. Science 236, 942-944.

Bahlburg, H., Weiss, R., Wünnemann, K., 2010. Low energy deposition in the Chicxulub crater during the impact to post-impact transition. Earth Planet. Sci. Lett. 295, 170-176.

Berger, W.H., 2011. Geologist at sea: aspects of ocean history. Ann. Rev Mar. Sci. 3, 1-34.

Blahüt, J., Balek, J. Klimeš, J., Rowberry, M., Kusák, M., Kalina, J., 2019. A comprehensive global database of giant landslides on volcanic islands. Landslides 16, 2045-2052.

Bland, P. A., Artemieva, N. A., 2003. Efficient disruption of small asteroids by Earth's atmosphere. Nature, 424, 288-291.

Bland, P. A., Artemieva, N. A., 2006. The rate of small impacts on Earth. Meteorit. Planet. Sci. 41, 607-631.

Bohor, B. F., 1996. A sedimentary gravity flow hypothesis for siliciclastic units at the K/T boundary, northeastern Mexico. In Ryder, G., Fastovsky, D., Gartner, S. (eds.), Cretaceous-Tertiary Event and Other Catastrophes in Earth History. Geol. Soc. Am. Spec. Pap. 307, pp. 183-195.

Bondevik, S., Gjevik, B., Sorensen, M., 2013. Norwegian seiches from the giant 2011 Tohoku earthquake. Geophys. Res. Lett. 40, 3374-3378.

Bourgeois, J., Hansen, T.A., Wiberg, P.L., Kauffman, E.G., 1988. A tsunami deposit at the Cretaceous-Tertiary boundary in Texas. Science 241, 567-570.

Bralower, T. J., Paul, C. K., Leckie, R. M., 1998. The Cretaceous/Tertiary boundary cocktail: Chicxulub impact triggers margin collapse and extensive sedimentary gravity flows. Geology 26, 331-334.

Carracedo, J.C., Day, S., Guillou, H., Pérez-Torrado, F.J., 1999. Giant Quaternary landslides in the evolution of La Palma and El Hierro, Canary Islands. Journal of Volcanology and Geothermal Research 94, 169-190. 
Chapman, C., Morrison, D., 1994. Impacts on the Earth by asteroids and comets: assessing the hazard. Nature 367, 33-40.

Cita, M. B., Camerlenghi, A., Rimoldi, B., 1996. Deep-sea tsunami deposits in the eastern Mediterranean: new evidence and depositional models. Sedimentary Geology 104, 155173.

Clément, J.P., Legendre, C., Caroff, M., Guillou, H., Cotten, J., Bollinger, C., Guille, G., 2002. Epiclastic deposits and 'horseshoe-shaped' calderas in Tahiti (Society Islands) and Ua HUka (Marquesas Archipelago), French Polynesia. Journal of Volcanology and Geothermal Research 120, 87-101.

Clouard, V., Bonneville, A., Gillot, P.Y., 2001. A giant landslide on the southern flank of Tahiti Island, French Polynesia. Geophysical Research Letters 28, 2253-2256.

Cooke, R.J.S., 1981. Eruptive history of the volcano at Ritter Island. Geological Survey of Papua New Guinea Memoir 10, 115-123.

Cornu, M.N., Paris, R., Doucelance, R., Bachélery, P., Guillou, H., 2017. Exploring the links between volcano flank collapse and magma evolution: Fogo oceanic shield volcano, Cape Verde. Geophysical Research Abstracts 13, EGU2017-4875-2.

Costa, A.C.G., Hildenbrand, A., Marques, F.O., Sibrant, A.L.R., Santos de Campos, A., 2015. Catastrophic flank collapses and slumping in Pico Island during the last $130 \mathrm{kyr}$ (PicoFaial ridge, Azores Triple Junction). Journal of Volcanology and Geothermal Research $302,33-46$.

Costard, F., Séjourné, A., Kelfoun, K., Clifford, S., Lavigne, F., Di Pxietro, I., Bouley, S., 2017. Modeling tsunami propagation and the emplacement of thumbprint terrain in an early Mars ocean. J. Geophys. Res. Planets 122, 633-649.

Costard, F., Séjourné, A., Lagain, A., Ormö, J., Rodriguez, J. A. P., Clifford, S., Bouley, S., Kelfoun, K., Lavigne, F., 2019. The Lomonosov crater impact event: A possible megatsunami source on Mars. J. Geophys. Res. Planets 124, 1840-1851.

Crook, K.A.W., Felton, E.A., 2008. Sedimentology of rocky shorelines: 5. The marine samples at $+326 \mathrm{~m}$ from 'Stearns swale' (Lanai, Hawaii) and their paleo-environmental and sedimentary process implications. Sedimentary Geology 206, 33-41. 
Dawson, A. Long, D., Smith, D. E., 1988. The Storegga Slides: Evidence from eastern Scotland for a possible tsunami. Mar. Geol. 82, 271-276.

Day, S.J., Heleno da Silva, S.I.N., Fonseca, J.F.B.D., 1999. A past giant lateral collapse and present-day flank instability of Fogo, Cape Verde Islands. Journal of Volcanology and Geothermal Research 99, 191-218.

DePalma, R.A., Smit, J., Burnham, D.A., Kuiper, K., Manning, P.L., Oleinik, A., Larson, P., Maurrasse, F., Vellekoop, J., Richards, M.A., Gurche, L., Alvarez, W., 2019. A seismically induced onshore surge deposit at the KPg boundary, North Dakota. Proceedings of the National Academy of Sciences 116, 8190-8199.

Dypvik, H., Jansa, L., 2003. Sedimentary signature and processes during marine bolide impacts: a review. Sedimentary Geology 161, 30-337.

Edgar, C.J., Wolff, J.A., Olin, P.H., Nichols, H.J., Pittari, A., Cas, R.A.F., Reiners, P.W., Spell, T.L., Martí, J., 2007. The late Quaternary Diego Hernandez Formation, Tenerife: volcanology of a complex cycle of voluminous explosive phonolitic eruptions. Journal Volcanology and Geothermal Research 160, 59-85.

Felton, E.A., Crook, K.A.W., Keating, B.H., Kay, E.A., 2006. Sedimentology of rocky shorelines: 4. Coarse gravel lithofacies, molluscan biofacies, and the stratigraphic and eustatic records in the type area of the Pleistocene Hulopoe Gravel, Lanai, Hawaii. Sedimentary Geology 184, 1-76.

Foeken, J.P.T., Day, S.J., Stuart, F.M., 2009. Cosmogenic ${ }^{3} \mathrm{He}$ exposure dating of the Quaternary basalts from Fogo, Cape Verdes: Implications for rift-zone and magmatic reorganisation. Quaternary Geochronology 4 (1), 37-49.

Fritz, H., Hager, W., Minor, H., 2004. Near Field Characteristics of Landslide Generated Impulse Waves. Journal of Waterway Port Coastal and Ocean Engineering 130, $287-$ 302.

Frohlich, C., Hornbach, M.J., Taylor, F.W., Shen C-C., Moala, A., Morton, A.E., Kruger, J., 2009. Huge erratic boulders in Tonga deposited by a prehistoric tsunami. Geology 37, 131-134. 
Franco, A., Moernaut, J., Schneider-Muntau, B., Aufleger, M., Strasser, M., Gems B., 2020. Lituya Bay 1958 Tsunami - detailed pre-event bathymetry reconstruction and 3Dnumerical modelling utilizing the CFD software Flow-3D. Natural Hazards and Earth System Sciences, 20, 2255-2279.

Froger, J.L., Famin, V., Cayol, V., Augier, A., Michon, L., Lénat, J.F., 2015. Time-dependent displacements during and after the April 2007 eruption of Piton de la Fournaise, revealed by interferometric data. Journal of Volcanology and Geothermal Research 296, $55-68$.

García-Olivares, V., López, H., Patiño, J., Alvarez, N., Machado, A., Carracedo, J.C., Soler, V., Emerson, B.C., 2017. Evidence for mega-landslides as drivers of island colonization. Journal of Biogeography 44, 1053-1064.

Gersonde, R., Kyte, F.T., Bleil, U., Diekmann, B., Flores, J.A., Gohl, K., Grahl, G., Hagen, R., Kuhn, G., Sierro, F.J., Volker, D., Abelmann, A., Bostwick, J.A., 1997. Geological record and reconstruction of the late Pliocene impact of the Eltanin asteroid in the southern ocean. Nature 390, 357-363.

Giachetti, T., Paris, R., Kelfoun, K., 2011. Numerical modelling of the tsunami triggered by the Güìmar debris avalanche, Tenerife (Canary Islands): comparison with field-based data. Marine Geology 284, 189-202.

Giachetti, T., Paris, R., Kelfoun, K., Ontowirjo, B., 2012. Tsunami hazard related to a flank collapse of Anak Krakatau volcano, Sunda Strait, Indonesia. Geological Society, London, Special Publication 361, 79-89.

Gisler, G., Weaver, R., Gittings, M., 2011. Calculations of asteroid impacts into deep and shallow water. Pure Appl. Geophys. 168, 1187-1198.

Goff, J., Chagué-Goff, C., Archer, M., Dominey-Howes, D., Turney, C., 2012. The Eltanin asteroid impact: possible South Pacific palaeomegatsunami footprint and potential implications for the Pliocene-Pleistocene transition. Journal of Quaternary Science 27, 660-670.

Goff, J., Terry, J., Chagué-Goff, C. and Goto, K. (2014) What is a megatsunami? Marine Geology, 358, 12-17. 
Goto, K., Tada, R., Tajika, E., Bralower, T. J., Hasegawa, T., Matsui, T., 2004. Evidence for ocean water invasion into the Chicxulub crater at the Cretaceous/Tertiary boundary. Meteorit. Planet. Sci. 39, 1233-1247.

Goto, K., Tada, R., Tajika, E., Matsui, T., Yamamoto, S., Nakano, Y., Oji, T., Kiyokawa, S., Gracia-Delgado, D. E., Otero, C. D., Consuegra, R.R., 2008. Lateral lithological compositional variations of the Cretaceous/Tertiary deep-sea tsunami deposits in northwestern Cuba. Cretaceous Ressearch 29, 217-236.

Goto, K., Kawana, T., Imamura, F., 2010. Historical and geological evidence of boulders deposited by tsunamis, southern Ryukyu Islands, Japan. Earth-Science Reviews 102, 77-99.

Goto, K., Iijima, Y., Wada, K., Imamura, F., Chang, Y., 2013. Tsunami risk assessment for the oceanic impact on Earth. Planetary People, Jpn. Soc. Planet. Sci. 22, 207-213 (in Japanese).

Gouhier, M., Paris, R., 2019. SO2 and tephra emissions during the December 22, 2018 Anak Krakatau flank-collapse eruption. Volcanica 2(2), 91-103.

Grigg, R.W., Jones, A.T., 1997. Uplift caused by lithospheric flexure in the Hawaiian archipelago, as revealed by elevated coral deposits. Marine Geology 141, 11-25.

Grilli, S. T., Watts, P., 2005. Tsunami generation by submarine mass failure. I: Modeling, Experimental Validation, and Sensitivity Analyses. Journal of Waterway, Port, Coastal, and Ocean Engineering 131, 283-297.

Grilli, S.T., Tappin, D.R., Carey, S., Watt, S.F.L., Ward, S.N., Grilli, A.R., Engwell, S.L., Zhang, C., Kirby, J.T., Schambach, L., Muin, M., 2019. Modelling of the tsunami from the December 22, 2018 lateral collapse of Anak Krakatau volcano in the Sunda Straits, Indonesia. Scientific Reports (2019) 9, 11946.

Gulick, S. P., Barton, P., Christeson, G., Morgan, J. V., McDonald, M., Mendoza-Cervantes, K., Pearson, Z. F., Surendra, A., Urrutia-Fucugauchi, J., Vermeesch, P. M., Warner, M. R., 2008. Importance of pre-impact crustal structure for the asymmetry of the Chicxulub impact crater. Nat. Geosci. 1, 131-135. 
Gulick. S.P.S., Bralower, T. J., Ormo, J., Hall, B., Grice, K., Schaefer, B., Lyons, S., Freeman, K. H., Morgan, J. V., Artemieva, N., Kaskes, P., de Graaff, S. J., Whalen, M. T., Collins, G. S., Tikoo, S. M., Verhagen, C., Christeson, G. L., Claeys, P., Coolen, M. J. L., Goderis, S., Goto, K., Grieve, R., McCall, N., Osinski, G. R., Rae, A., Riller, U., Smit, J., Vajda, V., Wittmann, A., Expedition 364 Scientists, 2019. The First Day of the Cenozoic. Proc. Natl. Acad. Sci. U.S.A. 116, 19342-19351.

Hassler, S.W., Simonson, B.M., 2001. The sedimentary record of extraterrestrial impacts in deep-shelf environments: evidence from the Early Precambrian. The Journal of Geology 109, 1-19.

Heidarzadeh, M., Satake, K., 2015. Source properties of the 1998 July 17 Papua New Guinea tsunami based on tide gauge records. Geophysical Journal International 202, 361-369.

Heidarzadeh, M., Satake, K., 2017. A Combined Earthquake-Landslide Source Model for the Tsunami from the 27 November 1945 Mw 8.1 Makran Earthquake. Bulletin of the Seismological Society of America 107, 1033-1040.

Hildebrand, A. R., Boynton, W. V., 1990. Proximal Cretaceous-Tertiary boundary impact deposits in the Caribbean. Science 248, 843-847.

Hildebrand, A. R., Penfield, G. T., Icring, D. A., Pilkington, M., Camargo, N., Jacobsen, S. B., Boynton, W. V., 1991. Chicxulub crater: A possible Cretaceous-Tertiary boundary impact crater on the Yucatàn Peninsula, Mexico. Geology 19, 867-871.

Hildenbrand, A., Gillot, P.Y., Bonneville, A., 2006. Offshore evidence for a huge landslide of the northern flank flank of Tahiti-Nui (French Polynesia). Geochemistry, Geophysics, Geosystems 7 (6), Q03006.

Hunt, J.E., Wynn, R.B., Masson, D.G., Talling, J., Teagle, D.A.H., 2011. Sedimentological and geochemical evidence for multi-stage failure of volcanic island landslides: a casestudy from Icod landslide on north Tenerife, Canary Islands. Geochemistry, Geophysics, Geosystems 12, Q12007.

Hunt, J.E., Wynn, R.B., Talling, J., Masson, D.G., 2013. Multistage collapse of eight western Canary Island landslides in the last 1.5 Ma: Sedimentological and geochemical evidence from subunits in submarine flow deposits. Geochemistry, Geophysics, Geosystems 14, 2159-2181. 
Hunt, J.E., Cassidy,, M., Talling, P.J., 2018. Multi-stage volcanic island flank collapses with coeval explosive caldera-forming eruptions. Scientific Reports (2018) 8, 1146.

Iijima, Y., Goto, K., Minoura, K., Komatsu, G., Imamura, F., 2014. Hydrodynamics of impactinduced tsunami over the Martian ocean. Planet. Space Sci. 95, 33-44.

Ikehara, K., Irino, T., Usami, K., Jenkins, R., Omura, A., Ashi, J., 2014. Possible submarine tsunami deposits on the outer shelf of Sendai Bay, Japan resulting from the 2011 earthquake and tsunami off the Pacific coast of Tohoku. Mar. Geol. 358, 120-127.

Imamura, F., Matsumoto, T., 1998. Field survey of the 1741 Oshima - Oshima tsunami (in Japanese). Rep. Tsunami Eng. Res. Tohoku University, 15, 85-105.

Imamura, F., Hashi, K., Imteaz, M. A., 2001. Modeling for tsunamis generated by landsliding and debris flow. In: Hebenstreit G.T. (eds) Tsunami Research at the End of a Critical Decade. Advances in Natural and Technological Hazards Research 18. Springer, Dordrecht, 209-228.

Ioki, K., Tanioka, Y., Yanagisawa, H., Kawakami, G., 2019. Numerical simulation of the landslide and tsunami due to the 1741 Oshima - Oshima eruption in Hokkaido, Japan. Journal of Geophysical Research: Solid Earth 124, 1991-2002.

Iwai, S., Goto, K., Ishizawa, T., 2019. A gigantic boulder transported by the 2011 Tohoku-oki tsunami. Island Arc 28, e12321.

Jansa, L. F., 1993. Cometary impacts into ocean -Their recognition and the threshold constraint for biological extinctions. Palaeogeogr. Palaeoclimatol. Palaeoecol. 104, 271286.

Johnson, R.W., 1987. Large-scale volcanic cone collapse: the 1888 slope failure of Ritter volcano. Bulletin of Volcanology 49, 669-679.

Kastens, K. A., Cita, M. B., 1981. Tsunami-induced sediment transport in the abyssal Mediterranean Sea. Geological Society of America Bulletin 92, 845-857.

Kawamata, K., Takaoka, K., Ban, K., Imamura, F., Yamaki, S., Kobayashi, E., 2005. Model of tsunami generation by collapse of volcanic eruption: The 1741 Oshima - Oshima 
tsunami. In: Satake K. (eds) Tsunamis. Advances in Natural and Technological Hazards Research 23, pp. 79-96 Springer, Dordrecht.

794 795

Kawata, Y., 2003, Risk management -Toward safety society. In Disaster Prevention 4 (DPRI eds.). 42-44.

Kelfoun, K., Giachetti, T., Labazuy, P., 2010. Landslide-generated tsunamis at Reunion Island. Journal of Geophysical Research 115, F04012.

Ketten, D.R., 1995. Estimates of blast injury and acoustic trauma zones for marine mammals from underwater explosions. Sensory Sys. Aquatic Mam., 391-407.

Kiyokawa, S., Tada, R., Iturralde-Vinent, M. A., Tajika, E., Yamamoto, S., Oji, T., Nakano, Y., Goto, K., Takayama, H., Delgado, D. G., Otero, C. D., Rojas-Consuegra, R., 2002. Cretaceous-Tertiary boundary sequence in the Cacarajicara Formation, western Cuba: An impact related, high-energy, gravity-flow deposit. In Koeberl, C., Macleod, G., (eds.) Catastrophic Events and Mass Extinctions: Impact and Beyond, Geol. Soc. Amer. Spec. Pap. 356, pp. 125-144.

Korycansky, D.G., Lynett, P.J., 2005. Offshore breaking of impact tsunami: the Van Dorn effect revisited. Geophysical Research Letters 32, L10608.

Kyte, F. T., Zhou, L., Wasson, J. T., 1988. New evidence on the size and possible effects of a late Pliocene oceanic impact. Science 241, 63-65.

Labazuy, P., 1996. Recurrent landsliding events on the submarine flanks of Piton de la Fournaise volcano (Reunion Island). In: McGuire, W.J., Jones, A.P., Neuberg, J. (Eds.), Volcano instability on the Earth and other planets. Geological Society, London, Special Publications 110, 293-306.

Lavigne, F., Paris, R., Grancher, D., Wassmer, P., Brunstein, D., Vautier, F., Leone, F., Flohic, F., De Coster, B., Gunawan, T., Gomez, Ch., Setiawan, A., Cahyadi, R., Fachrizal, 2009. Reconstruction of tsunami inland propagation on December 26, 2004 in Banda Aceh, Indonesia, through field investigations. Pure and Applied Geophysics 166, 259-281.

Lekkas, E.L., Andreadakis, E., Kostaki, I., Kapourani, E., 2013. A proposal for a new integrated tsunami intensity scale (IT IS-2012). Bulletin of the Seismological Society of America 103, 1493-1502. 
Le Roux, J.P., 2015. A critical examination of evidence used to re-interpret the Hornitos mega-breccia as a mass-flow deposit caused by cliff failure. Andean Geol. 42, 139-145.

Løvholt, F., Pedersen, G., Gisler, G., 2008. Oceanic propagation of a potential tsunami from the La Palma Island. Journal of Geophysical Research 113, C09026.

Løvholt, F., Pedersen, G, Harbitz, C.B., Glimsdal, S., Kim, J., 2015. On the characteristics of landslide tsunamis. Philosophical Transactions of the Royal Society A 373, 20140376.

Ma, G., Kirby, J. T., Hsu, T., Shi, F., 2015. A two-layer granular landslide model for tsunami wave generation: Theory and computation. Ocean Modelling 93, 40-55.

Madeira, J., Ferrer Gijón, M., Gonzalez de Vallejo, L.I., Andrade, C., Freitas, M., Lomoschitz, A., Hoffman, D.L., 2011. Agaete revisited: new data on the Gran Canaria tsunamiites. Geophysical Research Abstracts 13, EGU2011-2292-2.

Madeira, J., Ramalho, R., Hoffman, D.L., Mata, J., Moreira, M., 2020. A geological record of recurrent Pleistocene tsunami inundation in an oceanic island: the case of Maio, Cape Verde. Sedimentology, 67, 1529-1552.

Mader, C. L., 2002. Modeling the 1958 Lituya Bay mega tsunami, II . Science of Tsunami Hazards 20, 241-250.

Martí, J., Mitjavila, J., Araña, V., 1994. Stratigraphy, structure and geochronology of the Las Cañadas caldera, Tenerife, Canary Islands. Geological Magazine 131, 715-727.

Masson, D.G., Watts, A.B., Gee, M.R.J., Urgeles, R., Mitchell, N.C., Le Bas, T.P. Canals, M., 2002. Slope failures on the flanks of the western Canary Islands. Earth-Science Reviews $57,1-35$.

Masson, D.G., Le Bas, T.P., Grevemeyer, I., Weinrebe, W., 2008. Flank collapse and largescale landsliding in the Cape Verde Islands, off West Africa. Geochemistry, Geophysics, Geosystems 9, Q07015.

Matsui, T., Imamura, F., Tajika, E., Nakano, Y., Fujisawa, Y., 2002. Generation and propagation of a tsunami from the Cretaceous/Tertiary impact event. In Koeberl, C., Macleod, G., (eds.) Catastrophic Events and Mass Extinctions: Impact and Beyond, Geol. Soc. Amer. Spec. Pap. 356, pp. 69-77. 
850

851

852

853

854

855

856

857

858

859

860

861

862

863

864

865

866

867

868

869

870

871

872

873

874

875

876

Maurrasse, F. J. M. R., Sen, G., 1991. Impacts, tsunamis, and the Haitian Cretaceous-Tertiary boundary layer. Science 252, 1690-1693.

McHugh, C. M., Kanamatsu, T., Seeber, L., Bopp, R., Cormier, M-H., Usami, K., 2016. Remobilization of surficial slope sediment triggered by the A.D. 2011 Mw9 Tohoku-Oki earthquake and tsunami along the Japan Trench. Geology 44, 391-394.

McMurtry, G.M., Fryer, G.J., Tappin, D.R., Wilkinson, I.P., Williams, M., Fietzke, J., GarbeSchoenberg, D., Watts, P., 2004. Megatsunami deposits on Kohala volcano, Hawaii, from flank, collapse of Mauna Loa. Geology 32 (9), 741-744.

Meco, J., Scailet, S., Guillou, H., Lomoschitz, A., Carracedo, J.C., Ballester, J., Betancort, J.F., Cilleros, A., 2007. Evidence for long-term uplift on the Canary Islands from emergent Mio-Pliocene littoral deposits. Global and Planetary Change 57, 222-234.

Meco, J. (Ed.), 2008. Historia geológica del clima en Canarias. Monografia, Universidad Las Palmas de Gran Canaria, Spain, 296 pp.

Melosh, J., 2003. Impact-generated tsunamis: An over-rated hazard. Lunar and Planetary Science XXXIV. Abstract, \#2013.

Miller, D.J., 1960. Giant waves in Lituya Bay, Alaska. Geological Survey Professional Paper 354-C, U.S. Government Printing Office, Washington D.C.

Minoura, K., Nakaya, S., Sato, H., 1987. Traces of tsunamis recorded in lake deposits: An example from Jusan, Shiura-mura, Aomori. Zisin (J. Seismol. Soc. Jpn. 2nd ser.) 40, 183-196.

Mitchell, N.C., Quartau, R., Madeira, J., 2011. Assessing landslide movements in volcanic islands using near-shore marine geophysical data: south Pico island, Azores. Bulletin of Volcanology 74, 483-496.

Moore, J.G., Fornari, D.J., 1984. Drowned reefs as indicators of the rate of subsidence of the island of Hawaii. Journal of Geology 92, 753-759.

Moore J.G., Moore G.W., 1984. Deposit from a giant wave on the island of Lanai, Hawaii. Science 226, 1312-1315. 
Moore, J.G., Clague, D.A., Holcomb, R.T., Lipman, P.W., Normark, W.R., Torresan, M.E., 1989. Prodigious submarine landslides on the Hawaiian Ridge. Journal of Geophysical Research 94, 17465-17484.

Moore, J.G., Bryan, W.B., Ludwig, K.R., 1994. Chaotic deposition by a giant wave, Molokai, Hawaii. Geological Society of America Bulletin 106, 962-967.

Mori, N., Takahashi, T., 2012. The 2011 Tohoku earthquake tsunami joint survey group, 2012. Nationwide post event tsunami survey and analysis of the 2011 Tohoku earthquake tsunami. Coastal Engineering Journal 54, 27.

Muhari, A., Heidarzadeh, M., Susmoro, H., Nugroho, H.D., Kriswati, E., Supartoyo, Wijanarto, A.B., Imamura, F., Arikawa, T., 2019. The December 2018 Anak Krakatau volcano tsunami as inferred from post-tsunami field surveys and spectral analysis. Pure and Applied Geophysics 176, 5219-5233.

Muhari, A., Imamura, F., Arikawa, T., Hakim, A., Afriyanto, B., 2018. Solving the Puzzle of the September 2018 Palu, Indonesia, Tsunami Mystery: Clues from the Tsunami Waveform and the Initial Field Survey Data. Journal of Disaster Research 13, sc20181108.

Noda, A., Katayama, H., Sagayama, T., Suga, K., Uchida, Y., Satake, K., Abe, K., Okamura, Y., 2007. Evaluation of tsunami impacts on shallow marine sediments: an example from the tsunami caused by the 2003 Tokachi-oki earthquake, northern Japan. Sedimentary Geology 200, 314-327.

Normark, W.R, Moore, J.G., Torresan, M.E., 1993. Giant volcano-related landslides and the development of the Hawaiian Islands. In: Schwab, W.C., Lee, H. J., Twichell, D.C. (Eds.), Submarine Landslides: Selected Studies in the U.S. Exclusive Economic Zone. US Geological Survey Bulletin 2002, 184-196.

Nozaki, T., Ohta, J., Noguchi, T., Sato, H., Ishikawa, A., Takaya, Y., Kimura, J., Chang, Q., Shimada, K., Ishibashi, J., Yasukawa, K., Kimoto, K., Iijima, K., Kato, Y., 2019. A Miocene impact ejecta layer in the pelagic Pacific Ocean. Scientific Reports 9, 16111.

Oehler, J.-F., Labazuy, P., Lénat, J.F., 2004. Recurrence of major flank landslides during the last 2-Ma-history of Réunion Island. Bulletin of Volcanology 66, 585-598. 
906

907

908

909

910

911

912

913

914

915

916

917

918

919

920

921

922

923

924

925

926

927

928

929

930

931

932

933

Okamura, Y., Nishizawa, A., Fujii, Y., Yanagisawa, H., 2018. Accretionary prism collapse: a new hypothesis on the source of the 1771 giant tsunami in the Ryukyu Arc, SW Japan. Scientific Reports 8, 13620.

Ormö, J., Lindström, M., 2000. When a cosmic impact strikes the sea bed. Geological Magazine 137, 67-80.

Ormö, J., Dohm, J. M., Ferris, J. C., Lepinette, A., Fairén, A. G., 2004. Marine-target craters on Mars? An assessment study. Meteorit. Planet. Sci. 39, 333-346.

Paris, R. Wassmer, P., Sartohadi, J., Lavigne, F., Barthomeuf, B., Desgages, É., Grancher, D., Baumert, Ph., Vautier, F., Brunstein, D. , Gomez, Ch., 2009. Tsunamis as geomorphic crisis: lessons from the December 26, 2004 tsunami in Lhok Nga, west Banda Aceh (Sumatra, Indonesia). Geomorphology 104, 59-72.

Paris, R., Giachetti, T., Chevalier, J., Guillou, H., Frank, N., 2011. Tsunami deposits in Santiago Island (Cape Verde archipelago) as possible evidence of a massive flank failure of Fogo volcano. Sedimentary Geology 239, 129-145.

Paris, R., Kelfoun, K., Giachetti, T., 2013. Marine conglomerate and reef megaclasts at Mauritius Island (Indian Ocean): evidences of a tsunami generated by a flank collapse of Piton de la Fournaise volcano, Réunion Island? Science of Tsunami Hazards 32, 281291.

Paris, R., Coello Bravo, J.J., Martín González, M.E., Kelfoun, K., Nauret, F., 2017. Explosive eruption, flank collapse and mega-tsunami at Tenerife ca. 170 ky ago. Nature Communications 8, 15246.

Paris, R., Ramalho, R.S., Madeira, J., Ávila, S., May, S.M., Rixhon, G., Engel, M., Brückner, H., Herzog, M., Schukraft, G., Perez-Torrado, F.J., Rodriguez-Gonzales, A., Carracedo, J.C., Giachetti, T., 2018. Mega-tsunami conglomerates and flank collapses of ocean island volcanoes. Marine Geology, 395, 168-187.

Paris, A., Heinrich, P., Paris, R., Abadie, S., 2019. The December 22, 2018 Anak Krakatau, Indonesia, landslide and tsunami: preliminary modeling and results. Pure and Applied Geophysics 177, 571-590. 
Parker, T. J., Gorsline, D. S., Saunders, R. S., Pieri, D. C., Schneeberger, D. M., 1993. Coastal geomorphology of the Martian northern plains. Journal of Geophysical Research 98, 11061-11078.

Perez-Torrado, F.J., Paris, R., Cabrera, M.C., Schneider, J.L., Wassmer, P., Carracedo, J.C., Rodriguez Santana, A., Santana, F., 2006. The Agaete tsunami deposits (Gran Canaria): evidence of tsunamis related to flank collapses in the Canary Islands. Marine Geology $227(1-2), 137-149$.

Pimiento, C., Clements, C.F., 2014. When did Carcharocles megalodon become extinct? A new analysis of the fossil record. PLoS One 9, e111086.

Pimiento, C., Griffin, J.N., Clements, C.F., Silvestro, D., Varela, S., Uhen, M.D., Jaramillo, C., 2017. The Pliocene marine megafauna extinction and its impact on functional diversity. Nature Eco. Evo. 1, 1100.

Pyenson, N.D., Gutstein, C.S., Parham, J.F., Le Roux, J.P., Chavarría, C.C., Little, H., Metallo, A., Rossi, V., Valenzuela-Toro, A.M., Velez-Juarbe, J., Santelli, C.M., 2014. Repeated mass strandings of Miocene marine mammals from Atacama Region of Chile point to sudden death at sea. Pro. Roy. Soc. B: Biol. Sci. 281, 20133316.

Ramalho, R.S., Winclker, G., Madeira, J., Helffrich, G.R., Hipólito, A.R., Quartau, R., Adena, K., Schaefer, J.M., 2015. Hazard potential of volcanic flank collapses raised by new megatsunami evidence. Science Advances 1 (2015), e1500456.

Rubin, K.H., Fletcher III, C.H., Sherman, C., 2000. Fossiliferous Lanai'i deposits formed by multiple events rather than a single giant tsunami. Nature 408, 675-681.

Sassa, K., Dang, K., Yanagisawa, H., He B., 2016. A new landslide-induced tsunami simulation model and its application to the 1792 Unzen-Mayuyama landslide-andtsunami disaster. Landslides 13, 1405-1419.

Satake, K., Kato, Y., 2001. The 1741 Oshima-Oshima eruption: extent and volume of submarine debris avalanche. Geophysical Research Letters 28, 427-430.

Schulte, P., Alegret, L., Arenillas, I., Arz, J. A., Barton, P. J., Bown, P. R., Bralower, T. J., Christeson, G. L., Claeys, P., Cockell, C. S., Collins, G. S., Deutsch, A., Goldin. T. J., Goto, K., Grajales-Nishimura, J. M., Grieve, R. A. F., Gulick, S. P. S., Johnson, K. R., 
Kiessling, W., Koeberl, C., Kring, D. A., MacLeod, K. G., Matsui, T., Melosh, J., Montanari, A., Morgan, J. V., Neal, C. R., Nichols, D. J., Norris. R. D., Pierazzo, E., Ravizza, G., Rebolledo-Vieyra, M., Reimold, W. U., Robin, E., Salge, T., Speijer, R. P., Sweet, A. R., Urrutia-Fucugauchi, J., Vajda, V., Whalen, M. T., Willumsen, P. S., 2010. The Chicxulub asteroid impact and mass extinction at the Cretaceous-Paleogene boundary. Science 327, 1214-1218.

Schulte, P., Smit, J., Deutsch, A., Salges, T., Friese, A., Beichel, K., 2012. Tsunami backwash deposits with Chicxulub impact ejecta and dinosaur remains from the CretaceousPalaeogene boundary in the La Popa Basin, Mexico. Sedimentol. 59, 737-765.

Smit, J., Hertogen, J., 1980. An extraterrestrial event at the Cretaceous-Tertiary boundary. Nature, 285, 198-200.

Smit, J., Montanari, A., Swinburne, N.H.M., Alvarez, W., Hildebrand, A.R., Margolis, S.V., Claeys, P., Lowrie, W., Asaro, F., 1992. Tektite-bearing, deep-water clastic unit at the Cretaceous-Tertiary boundary in northeastern Mexico. Geology 20, 99-103.

Smit, J., Roep, Th. B., Alvarez, W., Claeys, P., Grajales-Nishimura, J. M., Bermudez, J. 1996. Coarse-grained, clastic sandstone complex at the K/T boundary around the Gulf of Mexico: Deposition by tsunami waves induced by the Chicxulub impact? In Ryder, G., Fastovsky, D., Gartner, S. (eds.), Cretaceous-Tertiary Event and Other Catastrophes in Earth History. Geol. Soc. Amer. Spec. Pap. 307, pp. 151-182.

Smit, J., 1999. The global stratigraphy of the Cretaceous-Tertiary boundary impact ejecta. Annual Review of Earth and Planetary Sciences 27, 75-113.

Smit, J., Gaast, V. D., Lustenhouwer, W., 2004. Is the transition impact to post-impact rock complete? Some remarks based on XRF scanning, electron microprobe, and thin section analyses of the Yaxcopoil-1 core in the Chicxulub crater. Meteorit. Planet. Space 39, $1113-1126$.

Spiske, M., Bahlburg, H., Weiss, R., 2014. Pliocene mass failure deposits mistaken as submarine tsunami back-wash sediments - An example from Hornitos, northern Chile. Sedimentary Geology 305, 69-82.

Stearns, H.T., 1938. Ancient shorelines on the islands of Lanai, Hawaii. Geological Society of America Bulletin 49, 615-628. 
Tada, R., Iturralde-Vinent, M.A., Matsui, T., Tajika, E., Oji, T., Goto, K., Nakano, Y., Takayama, H., Yamamoto, S., Rojas-Consuegra, R., Kiyokawa, S., García-Delgado, D., Díaz-Otero, Toyoda, K., 2003. K/T boundary deposits in the proto-Caribbean basin. American Association of Petroleum Geologists Memoir 79, 582-604.

Takabatake, T., Shibayama, T., Esteban, M., Achiari, H., Nurisman, N., Gelfi, M., Tarigan, T.A., Kencana, E.R., Fauzi, M.A.R., Panalaran, S., Harnantyari, A.S., Kyaw, T.O., 2019. Field survey and evacuation behavior during the 2018 Sunda Strait tsunami. Coastal Engineering Journal 61, 423-443.

Takayama, H., Tada, R., Matsui, T., Iturralde-Vinent, M. A., Oji, T., Tajika, E., Kiyokawa, S., García, D., Okada, H., Hasegawa, T., Toyoda, K., 2000. Origin of the Peñalver Formation in northwestern Cuba and its relation to $\mathrm{K} / \mathrm{T}$ boundary impact event. Sedimentary Geology 135, 295-320.

Tanaka, K. L., 1997. Sedimentary history and mass flow structures of Chryse and Acidalia Planitiae, Mars. Journal of Geophysical Research 102, 4131-4149.

Tappin, D., Grilli, S., Harris, J., Geller, R., Masterlark, T., Kirby, J., Shi, F., Ma, G., Thingbaijam, K. K. S., Mai, P., 2014. Did a submarine landslide contribute to the 2011 Tohoku tsunami? Marine Geology, 357, 344-361.

Tehranirad, B., Harris, J.C., Grilli, A.R., Grilli, S.T., Abadie, S., Kirby, J.T., Shi, F., 2015. Farfield tsunami threat in the north Atlantic basin from large scale flank collapses of the Cumbre Vieja volcano, La Palma. Pure and Applied Geophysics 172, 3589-3616.

Tsuji, Y., Nishihata, T., Saito, T., \& Sato, K., 2002. Distribution of heights of the tsunami caused by the 1741 Kampo eruption of volcano Oshima - Oshima, Hokkaido (in Japanese). Gekkan Kaiyo special issue, 28, 15-44.

Tsuji, Y., Kuroyanagi, Y., Narita, Y., Kinami, T., Shiraishi, M., Sato, M., et al., 2017. Height distribution of the tsunami accompanied with the 1741 Kampo volcanic eruption of the Oshima - Oshima Island on the coasts of Esashi and Matsumae districts, SW Hokkaido (in Japanese). Research Report of Tsunami Engineering, 33, 149-207.

Ulvrova, M., Paris, R., Nomikou, P., Kelfoun, K., Leibrandt, S., Tappin, D.R., McCoy, F.W., 2016. Source of the tsunami generated by the 1650 AD eruption of Kolumbo submarine 
volcano (Aegean Sea, Greece). Journal of Volcanology and Geothermal Research 321, 125-139.

Usami, K., Ikehara, K., Jenkins, R.G., Ashi, J., 2016. Benthic foraminiferal evidence of deepsea sediment transport by the 2011 Tohoku-oki earthquake and tsunami. Marine Geology 384, 214-224.

USGS, 2006. Landslide Types and Processes, Fact Sheet 2004-3072, URL: https://pubs.usgs.gov/fs/2004/3072/pdf/fs2004-3072.pdf

Verbeek, R.M., 1886. Krakatau. Batavia, Imprimerie de l'Etat, 567 p.

Ward, S.N., Asphaug, E., 2000. Asteroid impact tsunami: a probabilistic hazard assessment. Icarus 145, 64- 78 .

Ward, S.N., Asphaug, E., 2002. Impact tsunami-Eltanin. Deep-Sea Research II 49, 1073-1079.

Ward, S., Asphaug, E., 2003. Asteroid impact tsunami of 2880 March 16. Geophysical Journal International 153, F6-F10.

Ward, S. N., Day, S. 2001. Cumbre Vieja Volcano-Potential collapse and tsunami at La Palma, Canary Islands. Geophysical Research Letters 28, 3397-3400.

Watts, A.B. and Masson, D.G., 1995. A giant landslide on the north flank of Tenerife, Canary Islands. Journal of Geophysical Research 100, 24487-24498.

Watts, A.B. and Masson, D.G., 2001. New sonar evidence for recent catastrophic collapses of the north flank of Tenerife, Canary Islands. Bulletin of Volcanology 63, 8-19.

Webster, J.M., Clague, D.A., Braga, J.C., 2007. Support for the giant wave hypothesis : evidence from submerged terraces off Lanai, Hawaii. International Journal of Earth Sciences 96, 517-524.

Weiss, R., Lynett, P., Wünneman, K., 2015. The Eltanin impact and its tsunami along the coast of South America: insight for potential deposits. Earth and Planetary Science Letters 409, 175-181.

Weiss, R., Wünnemann, K., Bahlburg, H., 2006. Numerical modeling of generation, propagation and run-up of tsunamis caused by oceanic impacts: Model strategy and technical solutions. Geophysical Journal International 167, 77-88. 
1050 Wittmann, A., Kenkmann, T., Hecht, L., Stöffler, D., 2007. Reconstruction of the Chicxulub ejecta plume from its deposits in drill core Yaxcopoil-1. Geological Society of America Bulletin 119, 1151-1167.

1053 Wünnemann, K., Weiss, R., Hofmann, K., 2007. Characteristics of oceanic impact-induced large water waves-Re-evaluation of the tsunami hazard. Meteorit. Planet. Sci. 42, 18931903.

1056 Xenakis, A. M., Lind, S. J., Stansby, P. K., Rogers B. D., 2017. Landslides and tsunamis predicted by incompressible smoothed particle hydrodynamics (SPH) with application to the 1958 Lituya Bay event and idealized experiment. Proceedings of the Royal

Yanagisawa, H., 2018. Numerical simulation of the 1792 Mt. Mayuyama collapse and the resulting tsunami using two-layer model. Asia Oceania Geosciences Society (AOGS) (2018, Jun, Honolulu, Hawaii).

Yavari-Ramshe S., Ataie-Ashtiani B., 2016. Numerical modeling of subaerial and submarine landslide-generated tsunami waves - recent advances and future challenges. Landslides 13(6), 1325-1368. 


\section{Figure captions}

Fig. 1 - Tsunami size versus event probability (modified after Kawata, 2003), as seen from two different perspectives: disaster management, and geology.

Fig. 2 - Offshore to inland sediment transport during a mega-tsunami (here the source of the tsunami is a massive flank collapse from an oceanic island). A: the flank collapse from the source island produces a submarine debris avalanche with a volume of tens to hundreds of $\mathrm{km}^{3}$, and the mega-tsunami starts propagating in the ocean until it strikes another island (runup island); B: tsunami starts mobilising sediment on the shelf, including boulders; $\mathrm{C}$ : as the inundation progresses, sediment from different sources are mixed until a maximum altitude is reached (runup); D: tsunami backwash implies a remixing of the sediments deposited during the uprush inundation; E: idealized crosssections of sedimentary deposits resulting from a mega-tsunami generated by an ocean island flank collapse. Colours correspond to successive sediment sources from left

1083

Fig. 3 - Sediment transport processes acting during an impact tsunami. A: The impact of the asteroid with the water body (ocean, lake, etc.) normally generates a crater that (offshore) to right (inland). corresponds to the initial stage of the tsunami, as noted for explosion-generated tsunamis. B: The water crater then collapses and waves start propagating radially around the impact, while a large plume of ejecta is formed. C: While tsunami is propagating, seismic wave associated with the impact may trigger debris flows on submarine slopes. Ejecta are transported by density currents (collapsing plume) over the surface of the ocean, and then reworked as submarine suspension clouds. Wave ripples are formed in deep-water by the passage of the tsunami (e.g. Hassler and Simonson, 2001). D: Tsunami breaks on the shelf and erodes the substrate. Sediments deposited during inundation have a mixed marine - continental composition, including ejecta from the impact. E: A second generation of submarine debris flows is generated during the backwash of the tsunami, and oscillations produces compositional variations of the 

and $\mathrm{E}$ we refer to figure 1. 